\title{
Energy and Protein Consumption of Manggadong Rice as Local Wisdom and Effort of Staple Food Diversification
}

\author{
Evawany Aritonang ${ }^{\#}$, Evi Naria ${ }^{*}$, Ainun Rohana ${ }^{1}$ \\ \# Community Nutrition Department, University of Sumatera Utara, Jl Universitas No 21 Medan, 20155, Indonesia \\ E-mail: evawany@gmail.com \\ * Environment Health Department, University of Sumatera Utara, Jl Universitas No 21 Medan, 20155, Indonesia \\ E-mail: evi3@usu.ac.id \\ ${ }^{1}$ Agricultural Engineering Department, University of Sumatera Utara, Jl Dr Sofyan No 75 Medan, 20155, Indonesia \\ E-mail:ainunrhn@yahoo.com
}

\begin{abstract}
Carbohydrates as one of the macro nutrients have significant role in the food pattern in which 60-70\% of the recommended energy requirement comes from carbohydrates, and generally being a staple food. It is unfortunate that almost all people in Indonesia have made rice as the main source of carbohydrates and became a staple food. This situation affects the high dependence on rice. This study aims to modify manggadong as local wisdom into manggadong rice that is rice mixed with 4 types of cassava flour in cooking rice and analyze energy consumption and protein from manggadong rice. Intervention has 100 mothers as a sample. The results showed that the consumption of energy and protein manggadong rice of 4 types of cassava are arround $691 \mathrm{kcal}$ $729 \mathrm{kcal}$ and 12.7 to $12.9 \mathrm{~g}$. Manggadong rice consumption can reduce the consumption of energy and protein than rice without cassava flour. It recommended socialization of manggadong rice in society in order to be applied in staple food consumption to support food diversification program as an effort to create a household food security. Food industry must be support to provide cassava flour to facilitate the application of manggadong rice.
\end{abstract}

Keywords - Manggadong Rice, Energy and Protein Consumption, Local Wisdom, Food Diversification

\section{INTRODUCTION}

Household food security is the goal of national food security where every household can meet its food needs at any time, but this time illustrates the unsatisfactory condition [1]. This is evident from the number of households that have not received adequate food needs. Department of Health research results [2] shows that about 30\% of household consumption under proper consumption. In addition, more than a quarter of children under five have below standard weight (malnutrition) and $8 \%$ in very bad condition (malnutrition). Poor nutrition will hamper the normal growth of a child, endangering the health of the mother and reduce the productivity of the labor force. In addition it will also reduce the body's resistance to disease in a state of poor health and poverty [3].

Less food consumption includes consumption of macro nutrients and micro nutrients. Carbohydrates as one of the macro nutrients have a significant role in the consumption pattern in which $60-70 \%$ of the recommended energy requirement comes from carbohydrates, and generally become a staple source of food [4]. Food is pretty much the type of carbohydrate sources such as whole grains (rice), tubers, and corn; but it is unfortunate that almost all people in Indonesia have made rice as the main source of carbohydrates and become food pokok [3]. This situation affects the high dependence on rice, rice fulfillment becomes difficult, rice and other issues such as how to meet domestic consumption needs or problems of stability of rice prices to remain affordable by all parties. The total national rice consumption today is as high as 26.8 million tons per year, in addition to the consumption of rice per capita per year is also very high at $113 \mathrm{~kg} /$ capita / year in which Indonesia became the largest rice consuming country in the world [5].

Rice became a commodity whose role is the highest compared to other food. Even in the community had formed the habit of not eating that considers not eat rice even after eating noodles, bread, rice cake or other food. North Sumatra, which was once in the habit of eating potato either very supportive of the efforts to improve food security was not anymore. It also occurs in various regions in Indonesia, 
which was once in the habit of not eating rice mixed turns out today is not. Formerly Madura staple maize food consumption or food consumption Maluku first principal sago also slowly shifted to consumption of staple food rice. Based on this need to dig up the efforts of food habits are very good first period counts as local knowledge in an effort to reduce the consumption of rice and increase the food security of the family.

Manggadong an abbreviation of the Gadong mangalang in Batak language interpreted eat potatoes because "Gadong" in Batak language means potato. Eating yams are ancient tradition embraced people of North Sumatra, especially the ethnic Batak Tapanuli. Consumption of potatoes do well as main meals and snacks in a variety of activities. The habit of eating potato in antiquity because of poverty, which must eat potatoes before eating rice so when eating rice only slightly because the stomach is full with potatoes.

With better economic development and increasing purchasing power result in people no longer slowly consume potatoes before eating rice. This is unfortunate because it resulted in a very high dependency on rice supply even customary to have to eat rice and can not be replaced with another food. Cassava is an alternative source of carbohydrates which is much cheaper than rice. Sweet potatoes are one of the crops that can be developed in the diversification program. Sweet potatoes have some color, between white, yellow-colored, red to purple, turned out to have a relationship with nutrient content, particularly vitamins from yam.

In the use of raw materials for the manufacture of industrial products of potatoes have different kinds of colors for example to select raw materials producers Kremes fresh yams selecting materials yellowish flesh, while the sauce selected for reddish flesh color. In the production of sweet potato flour tends been having sweet potato flesh and skin color white this will affect the final result flour.

Based on this need to think of food as an alternative to rice diversification of food and nutrition efforts. One of the efforts is to assess local knowledge of North Sumatra in the field of food that stands manggadong mangalang Gadong (eating potato) before eating rice. Application of manggadong the daily consumption of rice modified into manggadong needs to be studied how the energy consumption and the resulting protein. This study aims to make rice flour mixed with 4 types of potato as a modification of local wisdom manggadong and analyze energy consumption and protein from rice flour mixed with 4 types of potato.

\section{MATERIALS AND METHODS}

\section{A. Types of Research}

This is an experimental study to create 4 types of potato flour mixed with rice in food consumption as a staple food in the form of technology manggadong program. This study was conducted at one of the District's largest potato production center in North Sumatra is District Pancur Batu Deli Serdang for 1 year in 2013. Making potato flour performed in the Laboratory of Agriculture Departement of Agriculture Engineering USU

\section{B. Population and Sample}

The population is all households in the District Pancur Batu Deli Serdang, while the sample was determined that a minimum sample of 100 households for survey research [7] . Respondents are housewife.

\section{Types and Data Collection Method}

This type of data is the primary data and secondary data. Primary data consist of household socio-economic characteristics were obtained by interviews, the consumption of energy and protein from rice manggadong.

\section{Material and Equipment}

The material used is rice and potatoes are 4 types of white sweet potato, purple sweet potato, orange sweet potato, and cassava to the characteristics of the material does not rot, does not change the color of the original, and fresh condition. The fourth type of potato used to be mixed with rice flour as will cook rice. Total consumption of rice and potato flour has a ratio of 15: 1 .

Equipment for the manufacture of potato flour : knife, telenan (cutting board), oven, tray, blender, basin and filter.

\section{E. Cassava Flour Production Method}

Fresh sweet potatoes are white sweet potato, purple sweet potato, orange sweet potato, and cassava peeled and cleaned (washed). Once clean potatoes sliced thin and dried with an electric oven for drying homogenize until totally dry $( \pm 12$ hours). Furthermore yams into flour until smooth in a blender and filtered (sifted) flour using a sieve. Finally ready to use potato flour in manggadong program.

\section{F. Intervention Manggadong}

Manggadong interventions conducted over 4 days for all samples by giving each $60 \mathrm{~g}$ potato flour for all kinds of sweet potatoes (4 types of potato flour). In a day panelists will use potato flour to cook rice in 2 times: first at the time of the morning and cook the rice when cooking rice both during the day / evening. Each panelist (sample) received $240 \mathrm{~g}$ potato flour will be cooked in accordance with the rules in Table I. Potato flour total given to all samples was $6000 \mathrm{~g}(6 \mathrm{~kg})$ for each type of potato.

TABLE I

USE of THE MiXed SWeEt RICE FLOUR WHEN COOKING RICE

\begin{tabular}{|c|c|c|c|}
\hline Day & Time & $\begin{array}{c}\text { Number } \\
\text { of Rice (g) }\end{array}$ & $\begin{array}{c}\text { Type Wheat } \\
\text { Flour }\end{array}$ \\
\hline First & $\begin{array}{l}\text { Morning } \\
\text { Afternoon / } \\
\text { Night }\end{array}$ & 450 & $\begin{array}{c}\text { white sweet } \\
\text { potatoes }\end{array}$ \\
\hline Second & $\begin{array}{l}\text { Morning } \\
\text { Afternoon / } \\
\text { Night }\end{array}$ & 450 & $\begin{array}{c}\text { purple sweet } \\
\text { potato }\end{array}$ \\
\hline $\begin{array}{l}\text { The } \\
\text { third }\end{array}$ & $\begin{array}{l}\text { Morning } \\
\text { Afternoon / } \\
\text { Night }\end{array}$ & 450 & $\begin{array}{c}\text { orange sweet } \\
\text { potato }\end{array}$ \\
\hline $\begin{array}{l}\text { The } \\
\text { fourth }\end{array}$ & $\begin{array}{l}\text { Morning } \\
\text { Afternoon / } \\
\text { Night }\end{array}$ & 450 & cassava \\
\hline Total & & 3600 & \\
\hline
\end{tabular}




\section{G. Processing and Data Analysis}

Energy and protein consumption data were analyzed descriptively by using a list of food composition set by the Ministry of Health. Manggadong contribution to energy and protein intake was calculated based on the amount of energy and protein present in potato and rice manggadong compared to the adequacy of energy and protein adults.

\section{RESULTS AND DISCUSSION}

\section{A. Flour Weight and Nutrition of Potatoes and Rice}

The average family consumes rice every day is $900 \mathrm{~g}$ and $60 \mathrm{~g}$ potato flour. Consumption is divided into 3 meals : breakfast, lunch, and dinner with a number of family members an average of 5 people. Average consumption of rice per person per day is 180 grams and yam flour consumption per person per day is 12 grams. Weight yam flour produced by electric oven drying method can be known from Table II.

TABLE II

Weight of Cassava Flour PROducEd By EleCtRIC Oven DRYING METHOD

\begin{tabular}{|c|l|c|c|}
\hline No & \multicolumn{1}{|c|}{ Type of cassava } & $\begin{array}{c}\text { Cassava } \\
\text { Weight }(\mathbf{g})\end{array}$ & $\begin{array}{c}\text { Weight Flour } \\
\text { Sweet }(\mathbf{g})\end{array}$ \\
\hline 1 & Purple sweet potato & 1000 & 280 \\
\hline 2 & Cassava & 1000 & 300 \\
\hline 3 & Orange sweet potato & 1000 & 200 \\
\hline 4 & Red sweet potato & 1000 & 340 \\
\hline
\end{tabular}

Based on Table II it is known that more red sweet potato flour which produces $340 \mathrm{~g}$ of red sweet potato flour 1000 grams of red sweet potato, yam while the least yield an orange sweet potato flour is that $200 \mathrm{~g} 1000 \mathrm{~g}$ orange sweet potato. Energy and protein content of rice and four kinds of potato can be seen from Table III.

TABLE III

Nutritional Content of Rice AND Potatoes Substance PER 100 GRAMS

\begin{tabular}{|c|l|c|c|}
\hline No & \multicolumn{1}{|c|}{ Food Substance } & $\begin{array}{c}\text { Energy } \\
(\mathbf{k c a l})\end{array}$ & $\begin{array}{c}\text { Protein } \\
(\mathbf{g})\end{array}$ \\
\hline 1 & Rice & 360 & 6.8 \\
\hline 2 & Sweet Purple Potato & 123 & 1.6 \\
\hline 3 & Cassava Rice & 146 & 1.2 \\
\hline 4 & Rice Sweet Orange Potato & 136 & 0.8 \\
\hline 5 & Rice Sweet Red Potato & 123 & 1.8 \\
\hline
\end{tabular}

\section{B. Energy and Protein Consumption of Potato in Rice Manggadong}

From Table I it can be seen that the rice manggadong known that the average rice consumption per person per day is 180 grams and yam flour consumption on average per person per day is 12 grams. Based on Table III note that the ratio between the energy content of rice and cassava it can be concluded that the energy content of potatoes $34-40 \%$ of the energy content of rice. This means that the energy per 100 grams of potato tubers $30-40 \%$ lower than the energy of rice per 100 grams of rice. While the protein content of cassava $11-26 \%$ of the protein content of rice. This means that the protein per 100 grams of potato tubers $10-25 \%$ lower than that of rice protein per $100 \mathrm{~g}$ of rice.

TABLE IV

THE AVERAGE OF ENERGY AND PROTEIN CONSUMPTION OF CASSAVA PER PERSON PER DAY

\begin{tabular}{|c|l|c|c|c|c|}
\hline No & \multicolumn{1}{|c|}{$\begin{array}{c}\text { Type } \\
\text { Cassava }\end{array}$} & $\begin{array}{c}\text { Flour } \\
\text { Consum } \\
\text { ption } \\
(\mathbf{g})\end{array}$ & $\begin{array}{c}\text { Consum } \\
\text { ption } \\
\text { of potato } \\
(\mathbf{g})\end{array}$ & $\begin{array}{c}\text { Energy } \\
(\mathbf{k c a l})\end{array}$ & $\begin{array}{c}\text { Protein } \\
(\mathbf{g})\end{array}$ \\
\hline 1 & $\begin{array}{l}\text { Sweet } \\
\text { Purple }\end{array}$ & 12 & 42.9 & 52.8 & 0.7 \\
\hline 2 & Cassava & 12 & 40 & 58.4 & 0.5 \\
\hline 3 & $\begin{array}{l}\text { Orange } \\
\text { Sweet } \\
\text { Potato }\end{array}$ & 12 & 60 & 81.6 & 0.5 \\
\hline 4 & $\begin{array}{l}\text { Red Sweet } \\
\text { Potato }\end{array}$ & 12 & 35.3 & 43.4 & 0.6 \\
\hline
\end{tabular}

From Table IV it is known that the highest energy intake derived from orange sweet potato, while the lowest energy intake derived from red sweet potatoes. Protein intake is relatively the same in all four types of potato is $0.5 \mathrm{gr}-0.7$ gr. Total energy and protein derived from rice manggadong can be used as dietary guidelines associated with the reduction of energy consumption and protein. When sufficient energy is based on an adult is $2000 \mathrm{kcal}$ and $48 \mathrm{~g}$ protein, the consumption of potatoes contributed $2.17 \%$ $4.1 \%$ of energy sufficiency and $1.04 \%-1.46 \%$ protein adequacy.

When sufficient energy is based on an adult is $2000 \mathrm{kcal}$ and $48 \mathrm{~g}$ protein then manggadong rice consumption contributed $34.6 \%-36.5 \%$ and $26.5 \%$ energy adequacy $26.9 \%$ protein adequacy. This is in accordance with general guidelines balanced nutrition that is the source of energy from carbohydrates is $30-40 \%$. Energy consumption is very high for rice can be reduced is to replace it with potato flour. Based on that need to be disseminated in the community manggadong rice and manufacturing of various types of potato starch by industry which allows people to apply this manggadong rice. Choice of potato flour consumed depends on how much energy and the expected contribution of each protein in the potato flour is staple food consumption.

\section{Consumption of Energy and Protein from Rice Manggadong}

Consumption of energy and protein from rice manggadong derived from rice and potato are shown in Table V. Consumption of rice per person per day is 180 grams manggadong rice and potato flour consumption per person per day is 12 grams.

When the consumption of potato flour $12 \mathrm{~g}$ per person per day was changed to the rice with the sense that the consumption of rice is $100 \%$ (not mixed with yam flour). The number of potatoes used in manggadong note from Table IV that when substituted into the rice then the amount of energy and protein will increase as shown in Table VI.

When sufficient energy is based on an adult is $2000 \mathrm{kcal}$ and $48 \mathrm{~g}$ protein then manggadong rice consumption contributed $34.6 \%-36.5 \%$ and $26.5 \%$ energy adequacy $26.9 \%$ protein adequacy. 
TABLE V

CONSUMPTION OF ENERGY AND PROTEIN FROM RICE MANGGADONG

\begin{tabular}{|l|c|c|c|c|c|c|}
\hline \multicolumn{1}{|c|}{$\begin{array}{c}\text { Type } \\
\text { of } \\
\text { Rice }\end{array}$} & $\begin{array}{c}\text { Cassava } \\
\text { Energy } \\
\text { (kcal) }\end{array}$ & $\begin{array}{c}\text { Rice } \\
\text { Energy } \\
\text { (kcal) }\end{array}$ & $\begin{array}{c}\text { Cassava } \\
\text { Protein } \\
(\mathbf{g})\end{array}$ & $\begin{array}{c}\text { Rice } \\
\text { Protein } \\
(\mathbf{g})\end{array}$ & $\begin{array}{c}\text { Total } \\
\text { Energy } \\
\text { (kcal) }\end{array}$ & $\begin{array}{c}\text { Total } \\
\text { Protein } \\
(\mathbf{g})\end{array}$ \\
\hline $\begin{array}{l}\text { Rice } \\
\text { Sweet } \\
\text { Purple } \\
\text { Potato }\end{array}$ & 52.8 & 648 & 0.7 & 12.2 & 700.8 & 12.9 \\
\hline $\begin{array}{l}\text { Cassava } \\
\text { Rice }\end{array}$ & 58.4 & 648 & 0.5 & 12.2 & 706.4 & 12.7 \\
\hline $\begin{array}{l}\text { Rice } \\
\text { Sweet } \\
\text { Orange } \\
\text { Potato }\end{array}$ & 81.6 & 648 & 0.5 & 12.2 & 729.6 & 12.7 \\
\hline $\begin{array}{l}\text { Rice } \\
\text { Sweet } \\
\text { Red } \\
\text { Potato }\end{array}$ & 43.4 & 648 & 0.6 & 12.2 & 691.4 & 12.8 \\
\hline
\end{tabular}

TABLE VI

CONSUMPTION OF ENERGY AND PROTEIN FROM RICE AS AMOUNT OF CASSAVA

\begin{tabular}{|c|l|c|c|c|c|}
\hline No & \multicolumn{1}{|c|}{$\begin{array}{c}\text { Material } \\
(\mathbf{g})\end{array}$} & $\begin{array}{l}\text { Energy } \\
\text { (kcal) }\end{array}$ & $\begin{array}{c}\text { Protein } \\
(\mathbf{g})\end{array}$ & $\begin{array}{c}\text { Energy } \\
\text { Sufficie } \\
\text { ncy (\%) }\end{array}$ & $\begin{array}{c}\text { Protein } \\
\text { Sufficiency } \\
(\%)\end{array}$ \\
\hline 1 & Rice 42.9 & 154.4 & 2.9 & 7.72 & 6.04 \\
\hline 2 & Rice 40 & 144 & 2.7 & 7.2 & 5.63 \\
\hline 3 & Rice 60 & 216 & 4.1 & 10.8 & 8.54 \\
\hline 4 & Rice 35.3 & 127.1 & 2.4 & 6.5 & 5.0 \\
\hline
\end{tabular}

This is in accordance with general guidelines balanced nutrition that is the source of energy from carbohydrates is $30-40 \%$. Energy consumption is very high for rice can be reduced is to replace it with potato flour. Based on that need to be disseminated in the community manggadong rice and manufacturing of various types of potato starch by industry which allows people to apply this manggadong rice. Choice of potato flour consumed depends on how much energy and the expected contribution of each protein in the potato flour is a staple food consumption.

When compared to Table IV to Table VI the energy consumption of potato flour is $40-80 \mathrm{kcal}$ much lower than if only to rice is $144-216 \mathrm{kcal}$. Similarly, a protein that is 0.5 to 0.7 grams of protein than rice alone is 2.4 to 4.1 gr. Especially when added to the rice consumption of 180 grams per person per day (648 kcal energy and $12.2 \mathrm{~g}$ protein) it will generate energy and protein intake as high as $792 \mathrm{kcal}$ $864 \mathrm{kcal}, 14.6 \mathrm{~g}$ protein, and - 16. 3 grams . Energy consumption and high protein is not in accordance with general guidelines balanced nutrition can affect a variety of diseases associated with the consumption of energy and high protein such as diabetes mellitus, obesity, hypertension, and other degenerative diseases.

\section{CONCLUSIONS}

Rice manggadong amount of energy in accordance with the guidelines amount of energy from carbohydrate in the general guidelines balanced nutrition is $30-40 \%$. Consumption of energy and protein rice flour manggadong of 4 types of potato are each $691 \mathrm{kcal}-729 \mathrm{kcal}$ and 12.7 to $12.9 \mathrm{~g}$. The research proves that manggadong rice consumption can reduce the consumption of energy and protein than rice consumption completely.

Necessity of rice manggadong socialization in the community in order to apply the staple food consumption to support food diversification program in an effort to achieve food security of the family and socialization manggadong rice based nutritional advantages of reducing the consumption of energy and protein high current tendency in society. Another recommendation is that efforts supplying potato flour in the community by the food industry to facilitate the application of rice manggadong.

\section{ACKNOWLEDGMENT}

We would like to thanks to the Directorate General of Higher Education The Ministry of Higher Education and Research on research grants by research scheme is competitive grant research of the fiscal year 2013/2014 and all those who cannot be mentioned one by one for their cooperation in this research.

\section{REFERENCES}

[1] Board of Food Security. Poverty Map of North Sumatra. 2010

[2] Department of Health. "Overview of Indonesia Statistic Health and the MDG's 2015". Health Minsitry in Indonesia. 2010

[3] Hardinsyah, D. Briawan, Retnaningsih, T. Herath \& R. Wijaya. "Needs Analysis of Food Consumption". Briefing Course of Nutritional Sciences and the National Congress PERSAGI $X$ in Bandung. 2002

[4] International Congress of Nutrition (ICN). Committee on World Food Security. Rome. 1992

[5] FAO. Measurement and Assessment of Food Deprivation and Under Nutrition. International Scientific Symposium. 26-28 June 2002 in Rome. Proceedings. 2003.

[6] Statistic Centre Office North Sumatra. "Welfare Statistics". Field. 2010

[7] Notoatmojo. Methodology for Health Research. Jakarta. Pustaka Rineka. 2003 